\title{
Identifikasi Materi Biologi SMA Sulit Menurut Pandangan Siswa Dan Guru SMA Se-Kota Salatiga
}

\author{
Sulasfiana Alfi Raida \\ INSTITUT AGAMA ISLAM NEGERI KUDUS JAWA TENGAH INDONESIA \\ Jl Conge Ngembalrejo Kotak Pos 51 Bae Kudus 59322 \\ alfira.biosains@gmail.com
}

\begin{abstract}
ABSTRAK
Penelitian ini merupakan penelitian pendahuluan yang dilakukan dengan tujuan untuk mengidentifikasi materi Biologi SMA Kelas XI semester gasal yang dipandang sulit menurut siswa dan guru. Penelitian ini menggunakan metode survei. Data dikumpulkan melalui angket yang melibatkan siswa SMA dengan populasi siswa SMA kelas XII jurusan IPA se-Kota Salatiga. Sampel penelitian diambil dengan teknik convenience sampling dan diperoleh siswa sebanyak satu kelas dari tiap sekolah. Responden lain dalam penelitian ini adalah guru. Responden tersebut merupakan guru yang mengampu mata pelajaran biologi kelas XI IPA di tiap sekolah. Data yang terkumpul diolah secara deskriptif dengan hasil sebagai berikut. Materi yang dianggap paling sulit oleh siswa dan guru adalah sama yaitu materi sistem regulasi. Materi yang dianggap sulit oleh siswa dan guru juga sama, yaitu materi sistem pertahanan tubuh. Siswa menyatakan bahwa materi tersebut dipandang paling sulit/ sulit dikarenakan konsep sulit dipahami dan materinya terlalu banyak. Berdasarkan hasil penelitian dapat disimpulkan bahwa materi sistem regulasi dan materi sistem pertahanan tubuh tergolong materi biologi SMA kelas XI yang sulit.
\end{abstract}

Kata Kunci: Materi Biologi Sulit, Siswa dan Guru.

\section{ABSTRACT}

This research is preliminary study that aimed to identify the materials of biology of the 4th semester IX classes of SMA which is considered difficult by students and teachers. The study was a survey. Collecting data used questionnaires involving SMA students with a population of XII-IPA class of SMA in Salatiga City. Samples were taken with convenience sampling technique and obtained by the students as much as one class from each school. Other respondents in this study were teachers. The respondent was a teacher who teaches biology of XI-IPA class at each school. The collected data was processed descriptively with the following results. The material was considered the most difficult by students and teachers is the same, that 
the regulatory system. Material that was considered difficult by students and teachers is the same, that the immune system. Students stated that those materials were considered the most difficult because of the concept was difficult to understand and the material was too much. Based on the results of the study, it can be concluded that the material of the regulatory system and the immune system are classified as a difficult biology materials of IX SMA class.

Keywords: difficult biology material, students and teachers

\section{PENDAHULUAN}

Sains khususnya biologi memiliki penting dalam segala aspek kehidupan manusia, terutama dalam bidang Saintek/ IPTEK. Penyajian biologi dalam pembelajaran ditujukan untuk menyiapkan masa depan siswa yang kritis, kreatif, kompetitif, mampu memecahkan masalah serta berani mengambil keputusan secara cepat dan tepat. Ke depannya siswa juga dapat survive secara produktif di tengah derasnya gelombang persaingan era digital global yang penuh peluang dan tantangan (Liliasari, 2011; Sudarisman; 2015).

Guru dalam rangka pencapaian tujuan pembelajaran biologi di atas, harus mampu memfasilitasi siswa agar mampu mencapai semua kompetensi pada tiap materi biologi. Namun, siswa seringkali tidak dapat mencapai kompetensikompetensi tersebut. Banyak siswa yang gagal mencapai KKM (Kriteria Ketuntasan Minimal) pada kompetensi pengetahuan, sikap, maupun keterampilan. Hal ini dikarenakan siswa merasa sulit menguasai materi yang disajikan oleh guru, sehingga tujuan pembelajaran yang telah dirancang tidak tercapai.

Materi-materi biologi sering dipandang siswa sebagai materi yang sulit dipelajari. Beberapa hal yang menyebabkan materi biologi sulit bagi siswa menurut Cimer (2012) sebagai berikut. (1). Karakteristik tiap materi biologi.Materi biologi memiliki konsep dan permasalahan kompleks yang harus dipelajari oleh siswa. Selain itu banyak objek biologi yang tidak dapat diamati secara langsung, bersifat abstrak, banyak menggunakan istilah asing/ latin. (2). Strategi pembelajaran yang disajikan oleh guru.Banyak guru yang masih menggunakan pembelajaran ceramah yang berpusat pada guru dan tidak mengaitkan dengan kehidupan sehari-hari. Hal ini menyebabkan siswa sulit memahami materi dan tidak termotivasi untuk mempelajari biologi lebih lanjut. (3). Kurangnya penguasaan guru.Guru hanya 
mentransfer pengetahuan yang terdapat pada buku pegangan. Guru tidak dapat mengembangkan materi yang disajikan dalam buku pegangan, sehingga siswa tidak tertarik terhadap materi yang disampaikan oleh guru. (4). Kebiasaan siswa belajar. Banyak siswa yang tidak rutin mempelajari materi biologi dan tidak mempelajari kembali materi yang telah diajarkan di kelas. (5). Kurangnya fasilitas pembelajaran. Ada beberapa sekolah yang tidak memiliki laboratorium, sehingga siswa tidak dapat melakukan kegiatan pengamatan maupun kegiatan eksperimen. (6). Kurangnya waktu pembelajaran. Materi biologi terdiri dari konsep dan permasalahan yang kompleks. Hal ini dirasa tidak imbang oleh siswa ketika siswa diminta mempelajarinnya dengan alokasi waktu yang sedikit/ terbatas.

Selain beberapa penyebab di atas, ada hal lain yang menyebabkan materi biologi dipandang sulit, yaitu: 1). materi biologi yang membahas mekanisme yang terjadi didalam tubuh menyulitkan belajar dan menyebabkan siswa mengalami miskonsepsi (Karagos, et.al., 2011); 2). Materi biologi yang dipandang sulit adalah materi yang berkaitan dengan organ dalam, sistem organ, dan mekanisme yang terjadi pada organ tubuh (Henno,et.al., 2008). Materi biologi yang membahas tentang sistem organ, dibelajarkan pada kelas XI semester genap. Materi-materi tersebut adalah sistem pencernaan, sistem pernapasan, sistem ekskresi, sistem regulasi, sistem reproduksi, dan sistem pertahanan tubuh.

Tidak hanya siswa, guru juga memandang ada beberapa materi yang dirasa sulit. Materi biologi yang dipandang sulit oleh siswa dan guru perlu dipelajari lebih lanjut oleh guru, kemudian dianalisis karakteristiknya, hingga penguasaan materi tersebut semakin mendalam. Dengan mengetahui materi-materi yang dianggap sulit oleh siswa dan diri sendiri, guru diharapkan dapat mengantisipasi kesulitan siswa dalam mempelajari materi tersebut.

Hal lain yang menyebabkan tujuan pembelajaran tidak tercapai adalah guru kurang memahami karakteristik materi yang dibelajarkan. Sudarisman (2015) menyatakan bahwa banyak guru yang mengalami kegagalan dalam pencapaiannya, karenaguru kurang memahami karakteristik materi diajarkan. Pemahaman tersebut sangat penting bagi guru, sebab berkaitan erat dengan penyiapan perangkat pembelajaran termasuk pemilihan strategi pembelajaran yang efektif dalam menyampaikan materi. 
Guru seringkali berupaya merancang strategi pembelajaran dalam rangka untuk mencapai tujuan pembelajaran. Guru membutuhkan referensi dari berbagai sumber, salah satunya berasal dari hasil penelitian. Berdasarkan sumber tersebut, guru dapat langsung menggunakan strategi pembelajaran yang digunakan dalam penelitian tersebut, ataupun memodifikasinya dengan menyesuiakan kondisi siswa dan lingkungan belajarnya.

Namun kenyataan terjadi adalah guru kerap menemui kendala dalam mencari referensi dari hasil penelitian materi yang dianggap sulit oleh guru dan siswa. Hal ini dikarenakan, materi yang dianggap sulit sering dihindari oleh peneliti.Perlu dilakukan suatu penelitian untuk menentukan materi yang dianggap paling sulit bagi siswa dan guru.Hal ini dilakukan agar materi tersebut dapat di analisis karakteristiknya dan selanjutnya dapat dilakukan perancangan strategi pembelajaran yang efektif untuk membelajarkannya.

Berdasarkan uraian di atas, maka materi yang dianggap sulit oleh siswa dan guru perlu diidentifikasi. Hal ini dilakukan sebagai penelitian pendahuluan untuk menentukan strategi pembelajaran biologi yang efektif, sesuai dengan karakteristik materi biologi yang dianggap sulit oleh siswa. Penelitian ini difokuskan pada ruang lingkup materi biologi kelas XI semester genap. Tujuan dari penelitian ini adalah untuk mengidentifikasi materi biologi kelas XI semester gasal yang paling dipandang sulit oleh menurut pandangan siswa dan guru.

\section{METODE PENELITIAN}

Metode yang digunakan dalam penelitian ini adalah metode surveiuntuk mengungkap secara deskriptif tentang identifikasi materi biologi yang dianggap sulit menurut pandangan guru dan siswa. Penelitian ini merupakan penelitian pendahuluan yang selanjutnya ditujukan untuk menentukan strategi pembelajaran biologi yang efektif, sesuai dengan karakteristik materi biologi yang dianggap sulit oleh siswa

Populasi adalah objek atau subjek yang memiliki karakteristik tertentu yang ditetapkan oleh peneliti untuk dipelajari dan kemudian ditarik kesimpulannya. Populasi penelitian ini adalah siswa SMA dan MA se-Kota Salatiga yang terdiri dari 9 sekolah. Semua responden merupakan siswa kelas XII jurusan/peminatan 
IPA yang telah melalui pembelajaran biologi kelas XI. Siswa tersebut merupakan siwa dari seluruh SMA dan MA se-Kota Salatiga.

Setelah menentukan populasi, tahap selanjutnya adalah menentukan sampel. Sampel adalah bagian dari populasi.Pengambilan sampel dilakukan dengan teknik convenience sampling, karena pengambilan sampel ditentukan oleh guru biologi masing-masing sekolah. Peneliti tidak memiliki kewenangan dalam menentukan sampel.Sampel yang diambil tiap sekolah antara lain: SMA Negeri 1 Salatiga sejumlah 57 siswa, SMA Negeri 2Salatiga sejumlah 35 siswa, SMA Negeri 3Salatiga sejumlah 38 siswa, SMA Muhammadiyah (Plus)Salatiga 15 siswa, SMA Kristen 1Salatiga sejumlah 23 siswa, SMA Kristen 2Salatiga sejumlah 11 siswa, SMA Theresiana sejumlah 9 siswa, SMA Kristen Satya Wacana sejumlah 22 siswa, dan MAN Salatiga Sejumlah 49 siswa.Selain siswa, responden lain dalam penelitian ini adalah guru. Responden tersebut merupakan guru yang mengampu mata pelajaran biologi kelas XI dari kesembilan sekolah di atas.

Data materi biologi sulit menurut pandangan siswa dan guru diperoleh melalui angket. Siswa dan guru diminta untuk menentukan materi dianggap paling sulit dan sulit diantara materi biologi kelas XI semester genap. Materi tersebut antara lain: sistem pencernaan, sistem pernapasan, sistem eksresi, sistem regulasi, sistem reproduksi, dan sistem pertahanan tubuh.

Selain materi, dalam angket juga dicantumkan sub-sub materi untuk mengingatkan kembali materi-materi biologi yang telah dipelajari pada kelas XI. Adapun sub materi pada tiap-tiap materi tersebut disajikan pada Tabel 1.

Tabel 1. Materi Biologi Kelas XI Semester Genap

\begin{tabular}{lll}
\hline No & \multicolumn{1}{c}{ Materi } & \multicolumn{1}{c}{ Sub Materi } \\
1. & $\begin{array}{l}\text { Sistem } \\
\text { Pencernaan }\end{array}$ & Struktur dan fungsi sistem pencernaan \\
& Zat Makanan \\
& Mekanisme sistem pencernaan \\
& Struktur pencernaan ruminansia \\
& Kelainan sistem pencernaan \\
2. & Struktur dan fungsi sel sistem pernapasan
\end{tabular}


Sistem

Pernapasan

Mekanisme Pernapasan pada manusia dan hewan

(serangga dan burung)

Kelainan sistem pernapasan

3. Sistem

Ekskresi

4. Sistem

Regulasi

Sistem saraf.

Sistem endokrin .

Sistem indera.

Mekanisme sistem regulasi.

Pengaruh psikotropika pada sistem regulasi.

Kelainan sistem regulasi.

5. Sistem

Reproduksi

Struktur dan fungsi alat-alat reproduksi pada laki-laki dan wanita.

Proses pembentukan sel kelamin

Ovulasi dan Menstruasi.

Fertilisasi, gestasi dan persalinan.

ASI dan KB

Kelainan/penyakit sistem reproduksi

6. Sistem

Pertahanan

Tubuh
Struktur dan fungsi sel sistem pertahanan tubuh

Antigen dan antibodi.

Mekanisme pertahanan tubuh.

Peradangan, alergi, pencegahan dan penyembuhan penyakit.

Imunisasi

Materi yang dianggap"paling sulit” diberi skor 3, sedangkan materi yang dianggap "sulit" diberi skor 2. Total skor pada tiap materi kemudian dibuat persentase untuk menentukan ututan materi yang paling dianggap sulit oleh siswa 
dan guru. Selain itu siswa dan guru juga diminta untuk memberikan alasan dari pemilihan materi yang dianggap sulit. Setelah siswa menentukan materi biologi yang sulit, siswa diminta untuk memberikan alasan penyebab materi tersebut sulit. Siswa diberikan pilihan penyebab materi tersebut sulit. Penyebab yang dapat dipilih oleh siswa antara lain: materi bersifat abstrak, konsep sulit dipahami, materi terlalu banyak, materi tidak menarik, dan materi dianggap tidak penting.Siswa diperbolehkan memilih lebih satu dan diperbolehkan memberikan alasan lain penyebab suatu materi biologi dipandang sulit. Sedangkan, penyebab materi biologi sulit oleh guru diketahui melalui teknik wawancara.

\section{HASIL DAN PEMBAHASAN}

Data skor materi Biologi sulit menurut pandangan siswa SMA Se-Kota Salatigaditampilkan dalam bentuk tabel.Data disajikan pada Tabel 2.

Tabel 2. SkorMateri Biologi Sulit Menurut Pandangan Siswa SMA Se-Kota Salatiga

\begin{tabular}{|c|c|c|c|c|c|c|c|}
\hline No & Sekolah & $\begin{array}{c}\text { Sistem } \\
\text { Pencernaan }\end{array}$ & $\begin{array}{c}\text { Sistem } \\
\text { Pernapasan }\end{array}$ & $\begin{array}{c}\text { Sistem } \\
\text { Ekskresi }\end{array}$ & $\begin{array}{c}\text { Sistem } \\
\text { Regulasi }\end{array}$ & $\begin{array}{c}\text { Sistem } \\
\text { Reproduksi }\end{array}$ & $\begin{array}{c}\text { Sistem } \\
\text { Pertahanan } \\
\text { Tubuh }\end{array}$ \\
\hline 1 & $\begin{array}{l}\text { SMA N } 1 \\
\text { SALATIGA }\end{array}$ & 33 & 0 & 7 & 110 & 55 & 80 \\
\hline 2 & $\begin{array}{l}\text { SMA N } 2 \\
\text { SALATIGA }\end{array}$ & 4 & 0 & 7 & 97 & 2 & 65 \\
\hline 3 & $\begin{array}{l}\text { SMA N } 3 \\
\text { SALATIGA }\end{array}$ & 9 & 7 & 7 & 97 & 7 & 63 \\
\hline 4 & $\begin{array}{l}\text { SMA KRISTEN } 1 \\
\text { SALATIGA }\end{array}$ & 5 & 0 & 9 & 65 & 22 & 12 \\
\hline 5 & $\begin{array}{l}\text { SMA KRISTEN } 2 \\
\text { SALATIGA }\end{array}$ & 9 & 3 & 0 & 27 & 3 & 13 \\
\hline 6 & $\begin{array}{l}\text { SMA KRISTEN } \\
\text { SATYA WACANA } \\
\text { SALATIGA }\end{array}$ & 23 & 0 & 0 & 57 & 0 & 25 \\
\hline 7 & $\begin{array}{l}\text { SMA } \\
\text { THERESIANA } \\
\text { SALATIGA }\end{array}$ & 0 & 0 & 0 & 24 & 0 & 17 \\
\hline 8 & $\begin{array}{l}\text { SMA MUHAM- } \\
\text { MADIYAH (PLUS) } \\
\text { SALATIGA }\end{array}$ & 5 & 3 & 7 & 39 & 2 & 19 \\
\hline \multirow[t]{2}{*}{9} & MAN SALATIGA & 9 & 0 & 11 & 138 & 11 & 72 \\
\hline & Total Skor & 97 & 13 & 48 & 654 & 102 & 366 \\
\hline
\end{tabular}

Persentase materi Biologi sulit menurut pandangan siswa SMA Se-Kota Salatiga dalam bentuk diagram batang dapat dilihat pada Gambar 1. 


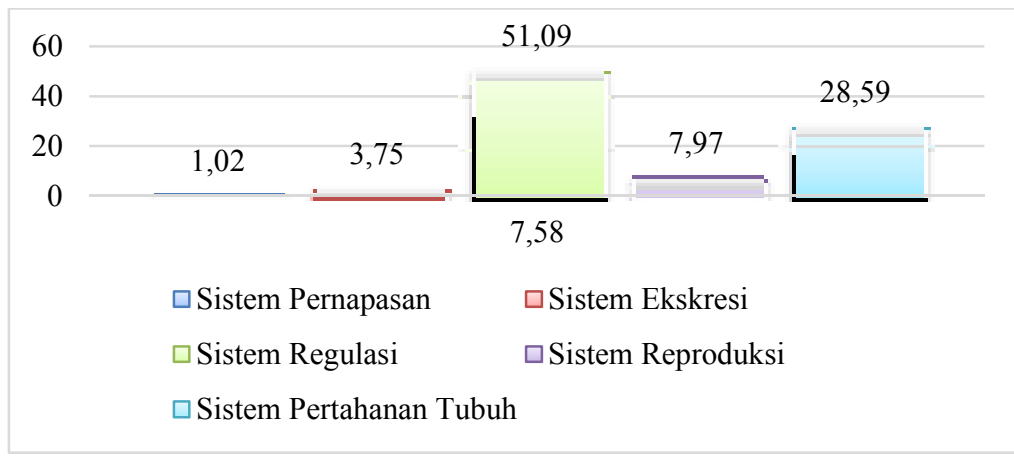

Gambar 1. Persentase materi biologi SMA sulit menurut pandangan siswa se-Kota Salatiga

Data yang tersaji pada Tabel 1 menunjukkan bahwa skor tertinggi materi biologi sulit menurut pandangan siswa terdapat pada materi sistem regulasi di semua sekolah. Sedangkan skor tertinggi selanjutnya terdapat pada materi sistem pertahanan tubuh di semua sekolah kecuali SMA Kristen 1 Salatiga. Skor tertinggi di sekolah tersebut, terdapat pada materi sistem reproduksi sebesar 25. Skor materi sistem pertahanan tubuh sebesar 12 .

Data materi biologi sulit menurut pandangan siswa lebih mudah dilihat pada Gambar 1 yang menyajikan gambar diagram batang dari hasil perhitungan persentase. Gambar 1 menunjukkan bahwa sebesar 51,09\% memandang materi sistem regulasi merupakan materi "paling sulit", dan sebesar 28,59\% memandang materi sistem pertahanan tubuh merupakan materi "sulit".

Data skor materi Biologi sulit menurut pandangan siswa SMA Se-Kota Salatigaditampilkan dalam bentuk tabel.Data disajikan pada Tabel 3.

Tabel 3. Skor Materi Biologi Sulit Menurut Pandangan Guru SMA Se-Kota Salatiga

\begin{tabular}{|c|c|c|c|c|c|c|c|}
\hline No & $\begin{array}{c}\text { Sekolah } \\
\text { Tempat Guru }\end{array}$ & $\begin{array}{c}\text { Sistem } \\
\text { Pencernaan }\end{array}$ & $\begin{array}{c}\text { Sistem } \\
\text { Pernapasan }\end{array}$ & $\begin{array}{c}\text { Sistem } \\
\text { Ekskresi }\end{array}$ & $\begin{array}{l}\text { Sistem } \\
\text { Regulasi }\end{array}$ & $\begin{array}{c}\text { Sistem } \\
\text { Reproduksi }\end{array}$ & $\begin{array}{c}\text { Sistem } \\
\text { Pertahanan } \\
\text { Tubuh }\end{array}$ \\
\hline 1 & $\begin{array}{l}\text { SMA N } 1 \\
\text { SALATIGA }\end{array}$ & 0 & 0 & 0 & 3 & 2 & 0 \\
\hline 2 & $\begin{array}{l}\text { SMA N } 2 \\
\text { SALATIGA }\end{array}$ & 0 & 0 & 0 & 2 & 0 & 3 \\
\hline 3 & $\begin{array}{l}\text { SMA N } 3 \\
\text { SALATIGA }\end{array}$ & 0 & 0 & 0 & 3 & 0 & 2 \\
\hline 4 & $\begin{array}{l}\text { SMA KRISTEN } 1 \\
\text { SALATIGA }\end{array}$ & 0 & 0 & 0 & 3 & 0 & 2 \\
\hline 5 & $\begin{array}{l}\text { SMA KRISTEN } 2 \\
\text { SALATIGA }\end{array}$ & 0 & 0 & 0 & 3 & 2 & 0 \\
\hline
\end{tabular}




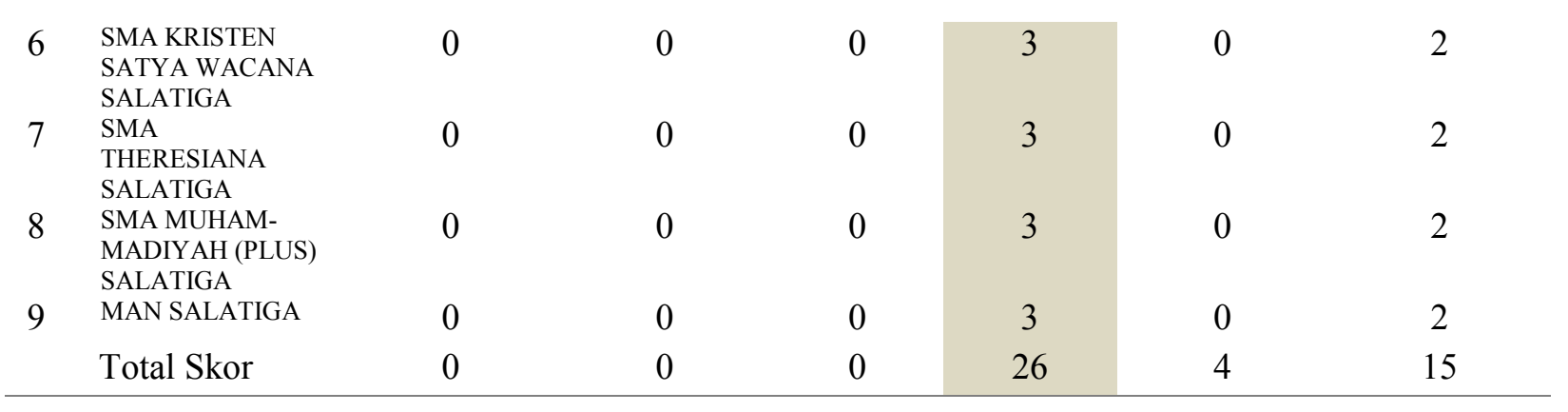

Persentase materi Biologi sulit menurut pandangan guru SMA Se-Kota Salatiga dalam bentuk diagram batang dapat dilihat pada Gambar 2.

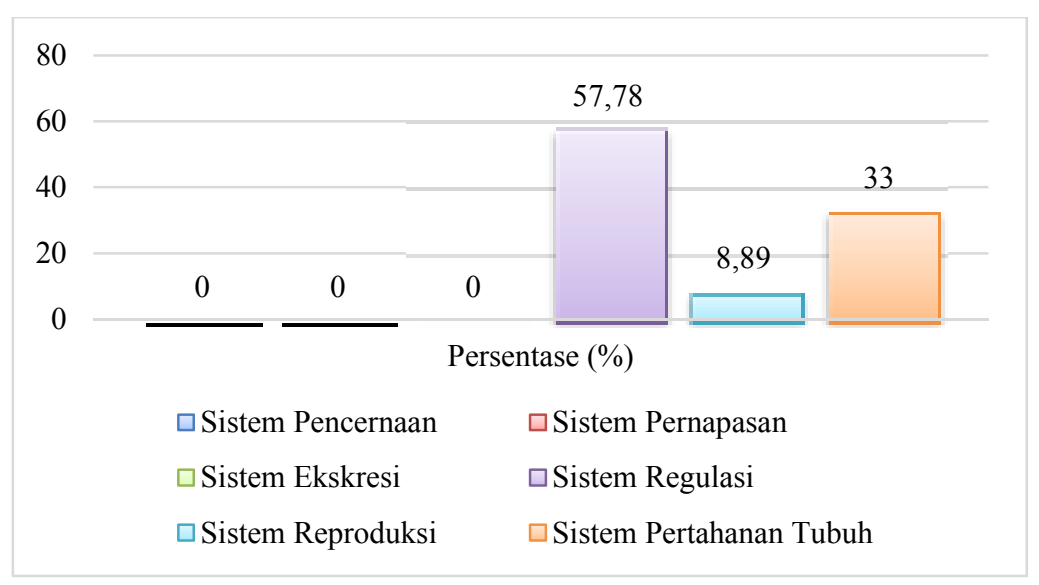

Gambar 2. Persentase materi biologi SMA sulit menurut pandangan guru se-Kota Salatiga

Data yang tersaji pada Tabel 2 menunjukkan bahwa skor tertinggi materi biologi sulit menurut pandangan guru terdapat pada materi sistem regulasi di semua sekolah, kecuali di SMA N 2 Salatiga. Guru di SMA tersebut memandang materi sistem pertahanan tubuh merupakan materi biologi paling sulit. Sedangkan skor tertinggi selanjutnya terdapat pada materi sistem pertahanan tubuh oleh guru di SMA N 3 Salatiga, SMA Kristen 1 Salatiga, SMA Kristen Satya Wacana, SMA Theresiana, SMA Muhammadiyah (Plus) Salatiga, dan MAN Salatiga.

Data materi biologi sulit menurut pandangan guru lebih mudah dilihat pada Gambar 2 yang menyajikan gambar diagram batang dari hasil perhitungan persentase. Berdasarkan Gambar 2menunjukkan bahwa sebesar 57,78\% guru memandang materi sistem regulasi merupakan materi "paling sulit", dan sebesar 33\% memandang materi sistem pertahanan tubuh merupakan materi“sulit”. 
Berdasarkan hasil penelitian di atas, dapat dilihat bahwa siswa dan guru sama-sama memandang materi sistem regulasi merupakan materi paling sulit. Sedangkan materi sistem pertahanan tubuh merupakan materi sulit.

Data alasan yang menjadi penyebab suatu materi biologi dipandang sulit disajikan dalam bentuk diagram batang dapat dilihat pada Gambar 3.

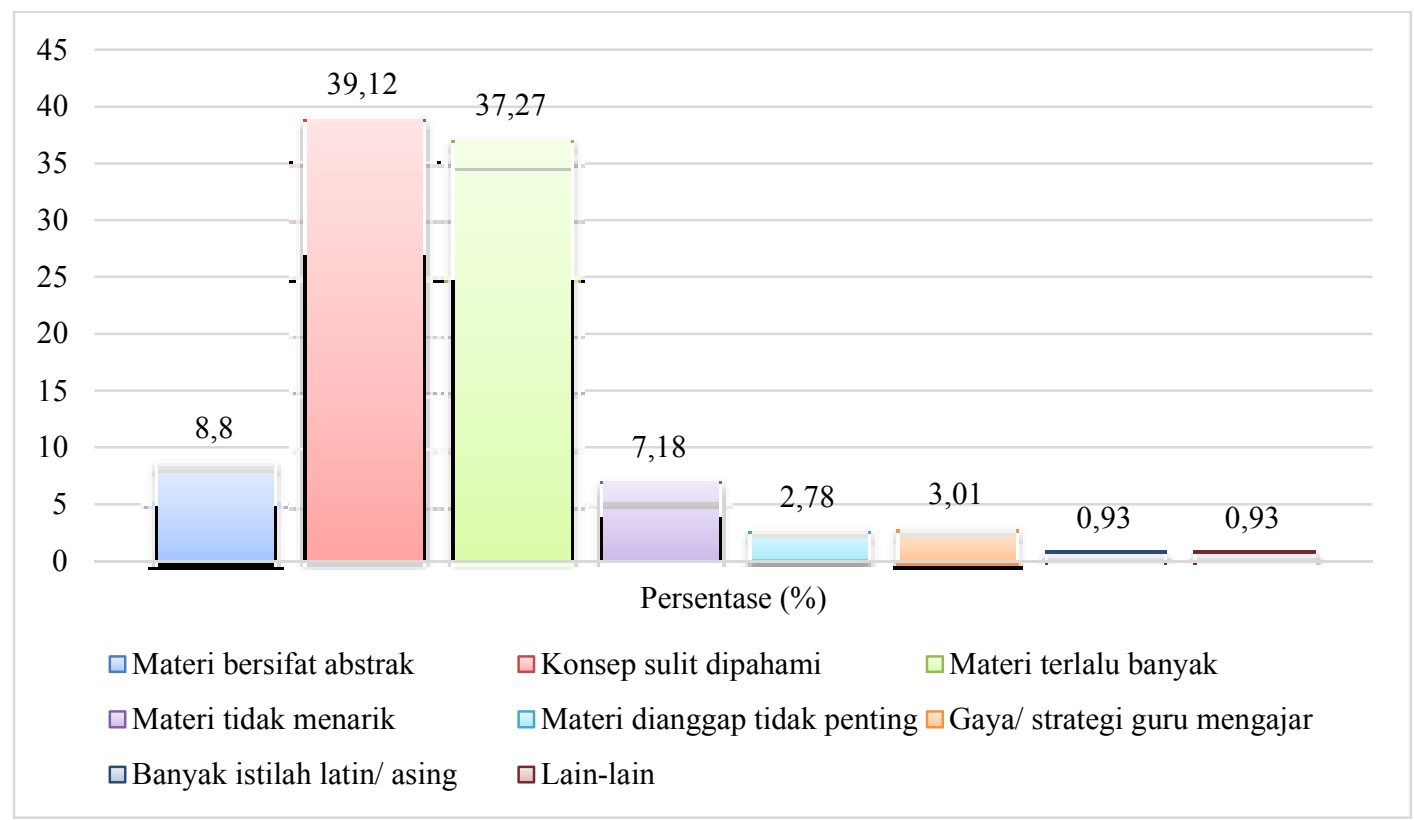

Gambar 3. Penyebab suatu materi biologi dipandang sulit oleh siswa SMA se-Kota Salatiga

Gambar 3 menunjukkan bahwa pandangan siswa tentang materi biologi sulit terutama materi sistem regulasi, paling banyak disebabkan oleh faktor konsep yang sulit dipahami dan materi yang terlalu banyak. Selanjutnya siswa memilih materi bersifat abstrak dan materi tidak menarik sebagai penyebab suatu materi dipandang sulit. Ada beberapa siswa $(0,93 \%)$ yang menambahkan penyebab lain selain penyebab yang disajikan di dalam angket. Hal tersebut diantaranya adalah materi membingungkan, materi rumit, waktu belajar yang terbatas, dan materi sulit dikaitkan dengan kehidupan-sehari-hari.

Berdasarkan hasil penelitian di atas siswa dan guru sama-sama memandang materi sistem regulasi merupakan materi paling sulit, dan materi sistem pertahanan tubuh merupakan materi sulit. Siswa merasa materi-materi tersebut memiliki konsep yang sulit yang dipahami, dan materi yang terlalu terlalu banyak. Jika 
melihat materi sistem regulasi dan materi sistem pertahanan tubuh, kedua penyebab yang paling banyak dipilih oleh siswa memang sesuai dengan karakteristik materi tersebut.

Materi sistem regulasi merupakan materi sistem organ yang disajikan pada kelas XI semester genap. Materi ini termasuk materi yang sulit dipahami karena di dalamnya terdapat sub materi mekanisme sistem regulasi. Sebagaimana yang disampaikan oleh Karagoset.al. (2011) dan Hennoet.al. (2008) bahwa suatu materi biologi dipandang sulit dikarenakan membahas tentang mekanisme pada organ tubuh. Mekanisme sistem organ yang dipelajari pada materi sistem regulasi dan sistem pertahanan tubuh merupakan materi yang abstrak yang menyajikan informasi yang sulit ditangkap oleh panca indera siswa secara langsung. Materi abstrak menyebabkan siswa mengalami miskonsepsi, seperti pada mekanisme penjalaran impulspada materi sistem saraf (Juhji, 2017).

Hal lain yang menyebabkan materi sistem regulasi sulit dikarenakan materi yang dipelajari terlalu banyak. Sub materi yang dipelajari pada materi sistem regulasi antara lain: struktur dan fungsi sel sistem regulasi, sistem saraf, sistem indera, sistem endokrin, mekanisme sistem regulasi, pengaruh psikotropika pada materi sistem regulasi, dan kelainan sistem regulasi.

Hasil penelitian ini didukung dengan analisis kesulitan materi sistem regulasi yang dilakukan oleh peneliti-peneliti sebelumnya. Beberapa kajian menyatakan bahwa kesulitan siswa dalam meguasai materi sistem regulasidan sub-sub materi sistem regulasi disebabkan oleh beberapa hal. Adapun penyebabnya antara lain: 1). cara belajar siswa yang cenderung menghapal karakteristik materi sistem regulasi yang bersifat abstrak, sulit menghubungkan antar konsep, siswa tidak dapat mengaitkan materi dalam kehidupan sehari-hari (Zulfiani et. al., 2012); materi sistem hormon terdiri dari materi yang sangat rumit, dan banyak menggunakan istilah asing/ menggunakan bahasa asing (Irmayanti et. al., 2017);kurangnya minat siswa mempelajari sistem indera, siswa sulit memusatkan perhatian pada penjelasan guru, dan strategi pembelajaran yang membosankan (Adriani \& Lazuardi, 2016); sistem endokrin merupakan materi sulit dikarenakan karakteristik materi biologi yang dipelajari berbasis pada hapalan, bersifat abstrak, terdiri atas kata latin, dan terdiri dari topik kompleks (Cimer, 2012). 
Materi sistem pertahanan tubuh juga memiliki kesamaan karakteristik dengan materi sistem regulasi. Materi sistem pertahanan tubuh bersifat abstrak, seperti hasil penelitian awal oleh Suhartono et. al. (2014) yang menyatakan bahwa materi sistem pertahanan tubuh merupakan materi sulit. Hal ini dikarenakan materi tersebut bersifat abstrak, menyulitkan siswa untuk membayangkan/ mengimajinasikan konsep-konsep didalamnya, terutama pada materi mekanisme kerja sistem imun. Dalam penelitian tersebut juga menyebutkan bahwa guru juga merasa kesulitan dalam merancang strategi pembelajarandikarenakan waktu pembelajaran materi sistem imun yang singkat. Sub materi pada materi sistem pertahanan tubuh juga tergolong banyak. Sub materi tersebut antara lain: struktur dan fungsi sel sistem pertahanan tubuh, antigen dan antibodi, mekanisme pertahanan tubuh, peradangan, alergi, pencegahan dan penyembuhan penyakit, serta imunisasi.

Hasil wawancara guru SMA se-Kota Salatiga juga menyatakan seperti hal di atas. Secara keseluruhan guru merasa kesulitan untuk menyajikan materi dalam waktu yang terbatas seperti pada materi sistem regulasi, sistem regulasi, dan sistem materi pertahanan tubuh. Sehingga untuk mengejar materi guru menyelesaikannya dengan metode ceramah. Berdasarkan temuan ini maka dalam menyikapi materi yang dipandang sulit oleh siswa dan guru, makaperan guru sangat diharapkan agar dapat mengatasi kesulita tersebut. Cimer (2012) menyarankan guru hendaknya menerapkan strategi pembelajaran efektif untuk mengatasi kesulitan dalam pembelajaran biologi. Guru dapat mengaitkan materi pembelajaran dengan fenomena dalam kehidupan sehari-hari. Guru juga perlu meningkatkan penguasaan konsep terhadap materi, agar siswa mudah dalam menerima pembelajaran (Haryaniet. al., 2014). Dengan demikian, maka guru perlu merancang strategi yang tepat sesuai dengan karakteristik materi, terutama materi sistem regulasi dan sistem pertahanan tubuh untuk mengatasi kesulitan siswa dalam mempelajarinya.

\section{SIMPULAN}

Berdasarkan temuan penelitian di atas, maka dapat disimpulkan bahwa materi yang dipandang paling sulit oleh guru dan siswa kelas XI IPA SMA adalah 
materi sistem regulasi. Materi yang dipandang sulit adalah materi sistem pertahanan tubuh. Siswa menyatakan bahwa materi-materi tersebut dipandang paling sulit/ sulit dikarenakan konsep sulit dipahami dan materinya terlalu banyak. Sedangkan guru menyampaikan bahwa guru merasa kesulitan untuk menyajikan materi-materi tersebut dikarenakan alokasi waktu yang terbatas. Berdasarkan hasil penelitian inidirasakan perlu adanya tindak lanjutpenelitian untuk menentukan strategi pembelajaran yang efektif untuk mengatasi kesulitan siswa dalam mempelajari materi sistem regulasi dan sistem pertahanan tubuh.

\section{DAFTAR PUSTAKA}

Adriani, S \& Lazuardi. 2016. Analisis kesulitan belajar siswa pada materi pokok sistem indra manusia (penglihatan, pendengaran, dan pengecap) di kelas XI IPA MAN 1 Stabat. Jurnal Pelita Pendidikan. 5 : 404-409.

Cimer, A. 2012. What makes biology learning difficult and effective: students' views. Educ Res Rev. 7(3): 61-71.

Haryani, S., Prasetya, A. P., \& Saptarini. 2014. Identifikasi materi kimia SMA sulit menurut pandangan guru dan calon guru kimia. Pemantapan Riset Kimia dan Asesmen Dalam PembelajaranBerbasis Pendekatan Saintifik. (Seminar Nasional Kimia dan Pendidikan Kimia VI).

Henno, I. \& Reiska, P. 2008. Using concept mapping as assessment tool in school biology. Concept Mapping: Connecting Educators. (Proc. Of the 3rd International Conference on Concept Mapping).

Irmayanti, Hasrudin, \& Kartika. 2017. Analisis kesulitan belajar siswa pada materi pokok hormon di kelas XI IPA SMA Negeri 1 Matauli Pandan tahun pembelajaran 2016/2017. Jurnal Pendidikan Matematika dan Sains. 12 (1): $1-6$.

Juhji. 2017. Upaya mengatasi miskonsepsi siswa pada materi sistem saraf melalui penggunaan peta konsep. Jurnal Formatif. 7(1): 33-39

Karagos, M. \& Cakir, M. 2011. Problem solving in genetics: conceptual and procedural difficulties. Educational Sciences: Theory \& Practice. 11(3): 1668-1674.

Liliasari. (2011). Membangun Masyarakat Melek Sains Berkarakter Bangsa Melalui Pembelajaran. [Online]. Diakses dari http://iliasari.staf.upi.edu/files/2011/05/Makalah-SemnasUNNES2011.Liliasari.pdf. 
Sudarisman, S. 2015. Memahami hakikat dan karakteristik pembelajaran biologi dalam upaya menjawab tantangan abad 21 serta optimalisasi implementasi Kurikulum 2013. Jurnal Florea. 2 (1): 29-35.

Suhartono, B. S., Suarsini, E., \& Tenzer, A. 2014. Pengembangan Multimedia Interaktif Berbasis Flash untuk Meningkatkan Hasil Belajar Siswa pada Pembelajaran Sistem Imun untuk Kelas XI SMA. [Online]. http://jurnalonline.um.ac.id/data/artikel/artikelF324D4E39CD052DD3FA060E5A4A D752C.pdf

Zulfiani, Marlina, R., \& Panjaitan, R. G. B. 2012. Analisis kesulitan belajar siswa pada konsep sistem regulasi manusia di kelas XI SMAN 4 Pontianak. Jurnal Ilmiah Al Ribaath LPPN UNMUH Pontianak. 9 (1): 65-69. 